\title{
The long and winding road 1
}

\begin{abstract}
In this article, the author reviews the tortuous path to EU membership being experienced by countries from south-eastern Europe. Identifying that the EU must consolidate the achievements of previous integrations while grappling with the implications of the 'truly new' European project in which it is now engaged, the author calls for a 'new strategic thinking' to cope with the complexity of the issues involved. The article sets out the momentum which has been lost and the factors which explain enlargement fatigue and the EU's period of reflection over its continued expansion, which have led to a gap between achievements in technical terms and the political will required to respond, as well as a deepening of the demands placed on the countries of south-east Europe. The author concludes by calling for a 'member state-building strategy' based on delivering a more promising prospect of EU membership accompanied by specific strategies to address issues of development and growth, within the framework of a regional cohesion programme favouring social inclusion.
\end{abstract}

Keywords: European Union, accession process, integration, transition, reform, southeast Europe, Copenhagen Criteria, enlargement fatigue, absorption capacity, financial crisis, regional co-operation

The broader picture - the SEE levels

Europe - and this does not mean exclusively the European Union (EU) - is completely different from what it was some twenty years ago. Following the fall of the Berlin Wall, unpredicted geopolitical changes have given the continent a new order of peace and security and a novel architecture. ${ }^{2}$ After the fifth and biggest ever enlargement, ${ }^{3}$ the EU must now - in a quite different historical context - cope with the consequences of two decades of unprecedented success in terms of integration and enlargement.

1 Most of this article was presented as background material for the seminar "Avoiding the "Turkey Game" in the Western Balkans', organised by the Bruno Kreisky Forum for International Dialogue and the Centre for Liberal Studies, in partnership with the Renner Institute and the Robert Bosch Foundation on 7-10 December 2010 in Vienna. Part of the arguments were first published as Rethinking the Process of EU Integration in the Balkans CEIS Working Paper Series, 2009: 3.

2 Michel Foucher (2009) L'Europe et l'avenir du monde Paris: Odile Jacob.

3 On 1 May 2004, the EU welcomed ten more member states: Cyprus; the Czech Republic; Estonia; Hungary; Latvia; Lithuania; Malta; Poland; Slovakia; and Slovenia. This was the fifth time that the EU had accepted new members, bringing the total from 15 to 25 member states. On 1 January 2007, the latest round of enlargement ended with the accession of two more countries, Bulgaria and Romania. 
The EU must consolidate these achievements for the future but Brussels is, at the same time, facing the challenges of a truly new European political project. First, the EU needs to reorient its relations with its neighbouring areas, i.e. the countries located between the EU and the Russian Federation. ${ }^{4}$ It must use in a much more assertive way its three main tools: the enlargement policy in south-eastern Europe; the European Neighbourhood Policy (ENP) in the east; and the strategic partnership with Russia. Second, the EU has to envision a flexible architecture, taking into account the panEuropean dimension and the evolving nature of regional co-operation as 'open regionalism' ${ }^{5}$ - as illustrated by the dynamism of interconnected sub-regions such as southeast Europe and the Black Sea area. Third, the EU is increasingly facing multi-dimensionality and fluidity - multi-actor, multi-level and multi-scalar processes, forming a complex geometry of interlocking networks - and so it must develop 'network power'. ${ }^{6}$

These issues are crucial for the EU if it wants to gain relevance and even more so for south-east European states as they may play a key role in a pan-European framework due to their geo-strategic position - bridging the Danube region, central and eastern Europe, western Asia and the Russian Federation. What should be borne in mind is that south-east Europe is a 'region of overlapping regions'; ${ }^{7}$ and, therefore, it is not a homogeneous region but rather a multi-faceted network linked to other networks. This is best illustrated by the regional co-operation schemes which are evolving inside but also outside the EU in the direction of an inter-penetration between the interior and exterior of states, virtually producing a 'de-borderisation' as well as, at the same time, a 'nostalgia for roots and walls' ${ }^{8}$

Only a flexible architecture and strategy may overcome what could be viewed as new dividing lines between EU member states encompassing the latest enlargement, 'would-be' (thus, south-east European) EU members and those countries which are explicitly precluded from EU accession - such as Ukraine, the Russian Federation and the Caucasian states. New strategic thinking is also needed in order to be able to cope with the greater complexity resulting from, first, the relations among south-east European countries (sub-regional co-operation and multiple bilateral issues) and their respective partnership with the EU; and, second, the co-existence of numerous programmes - such as the pre-accession process, the ENP, the strategic partnership with

4 Fyodor Lukyanov (2010) 'Building Greater Europe' Russia in Global Affairs 25 October.

5 Christophe Solioz and Paul Stubbs (2009) 'Emergent regional co-operation in South East Europe: towards 'open regionalism'?' Southeast European and Black Sea Studies 9(1): 1-16.

6 Janine Wedel (2009) Shadow Elite New York: Basic Books, p. 23 and p. 26; David Singh Grewal (2008) Network Power New Haven: Yale University Press; and Solioz and Stubbs (2009) op. cit.

7 Vladimir Gligorov (1998) 'Trade and Investment in the Balkans' in: Vladimir Gligorov and Hermine Vidovic (Eds.) On the Way to Normality: The States on the Territory of Former Yugoslavia in the Postwar Period Vienna: wiiw Paper, No. 250, p. 2.

8 Pierre Hassner (2002) 'Fixed Borders or Moving Borderlands?: A New Type of Border for a New Type of Entity' in: Jan Zielonka (Ed.) Europe Unbound. Enlarging and Reshaping the Boundaries of the European Union London and New York: Routledge, pp. 38-50. 
the Russian Federation, numerous bilateral agreements, various action plans and the wide range of EU and $\mathrm{CoE}$ cross-border, transitional and inter-regional programmes. ${ }^{9}$

\section{From Thessaloniki to Lisbon - the lost momentum}

Following the 1997 EU Regional Approach for the Western Balkans, the Stabilisation and Association Process (SAP) - as a tailor-made, country-by-country, progressive approach and intermediate step on the path towards accession - has, since May 1999, been the centrepiece of EU strategy towards this region. ${ }^{10}$ On 19 and 20 June 2000, at the Santa Maria de Feira European Council, all western Balkan countries were considered as potential candidates for EU membership while, on 24 November 2000, the prospect of possible accession to the EU was confirmed at the Zagreb Summit. Two years later, the European Commission (EC) convincingly expressed a major shift in the Union's approach to the western Balkans:

EU leaders decided that a policy of emergency reconstruction, containment and stabilisation was not, in itself, enough to bring lasting peace and stability to the Balkans: only the real prospect of integration into European structures would achieve that. ${ }^{11}$

At the June 2003 Thessaloniki Summit, the EU made the unequivocal promise that western Balkan countries could join the Union provided that they bring themselves up to EU standards by fulfilling the four Copenhagen conditions for entry ${ }^{12}$ and by adopting the acquis communautaire. ${ }^{13}$ The Thessaloniki declaration gave the concrete prospect of membership, but the Thessaloniki Agenda for the western Balkans emphasised the need to upgrade regional co-operation, to strengthen the SAP and to intensify relations between the western Balkans and the EU through the introduction of European Partnerships - following the successful experiment with national programmes for the adoption of the acquis in the accession process of central and east European countries.

9 Christophe Solioz (2008) 'Thinking About and Beyond South East Europe' in: Wolfgang Petritsch and Christophe Solioz (Eds.) Regional Cooperation in South East Europe and Beyond Baden-Baden: Nomos, p. 24 and p. 168.

10 The SAP was officially launched at the Zagreb Summit on 24 November 2000. The Summit's final declaration mentions the SAP as a 'Stabilisation and Association Process on an Individualised Basis'.

11 Commission of the European Communities (2002) The Stabilisation and Association Process for South East Europe, First Annual Report Brussels: COM(2002)163 final, 4 April, p. 4.

12 The four 'Copenhagen conditions' - democracy and the rule of law; a market economy; the capacity to meet the obligations of membership; and the EU's capacity to absorb new members - were set at the Copenhagen European Council in 1993 and went beyond those for any previous applicant.

13 The term acquis communautaire - corresponding to the third of the Copenhagen conditions - first refers to the legal embodiment of existing and settled EU policies and, second, encompasses EU values and policy objectives. Thus, the term refers in a broader sense to 'all real and potential rights and obligations of the EU system and its institutional framework' (Uniting Europe No. 9, 13 April 1998). 
The Thessaloniki Summit was greeted with satisfaction, if not euphoria, by many commentators. This renewal of European strategies and perspectives for the western Balkans, combined with a number of coherent practical and symbolic measures, eventually marked the end of clientelistic bilateral manoeuvrings between EU member states and the individual states of the region. ${ }^{14}$

At the time of the Thessaloniki Summit, some major think tanks were lobbying for a strengthened accession process. The European Stability Initiative suggested applying strategies - cohesion policy or structural policy - based on the European regional development policy. ${ }^{15}$ The International Crisis Group also focused on a more vigorous approach, suggesting a set of technical means ranging from increased financial assistance to effective twinning arrangements and regional integration. ${ }^{16}$ Two years later, the more comprehensive report of the International Commission on the Balkans recommended a 'member-state-building' strategy, focusing on the necessity to include institution- and thus capacity-building into the negotiating framework. ${ }^{17}$ These were all outstanding - and still relevant - proposals but, very unfortunately, they were not able to revitalise the EU integration process nor counteract the 'enlargement fatigue' which was about to obstruct the accession prospect.

Where do we stand eight years later? From the Balkan area, only Slovenia (since May 2004), Bulgaria and Romania (since January 2007) have become fully-fledged EU members. All the other countries - which have, meanwhile, been granted visa-free travel to the EU - are still knocking on the door: Croatia and Macedonia as candidate countries; Albania, Bosnia and Herzegovina, Montenegro and Serbia as potential candidate countries. The first enlargement package of the new Commission working under the Lisbon Treaty, presented on 9 November 2010, proposes candidate status for Montenegro and recommends that accession negotiations with Montenegro and Albania should be opened:

Once these countries have met a number of key priorities set out in the opinions.

As of now, all the countries are in the slow lane and in a state of strategic uncertainty. How come?

As a matter of fact, the Thessaloniki enthusiasm quickly vanished. First, mixed signals had already arrived in 2004, when the EU - in its draft Instrument of PreAccession Assistance (IPA) - assumed that countries from the region would eventually be able to achieve candidate status around 2010 and actual membership

14 Haralambos Kondonis (2005) 'Greek presidency: what lies behind the euphoria' in: David A. Stone and Despina Syrri (Eds.) Integrating the Western Balkans into Europe: the Aftermath of the Greek EU Presidency Thessaloniki: South-East European Research Center, pp. 47-52.

15 European Stability Initiative (2003) The Road to Thessaloniki: Cohesion and the Western Balkans Berlin: ESI, 12 March.

16 International Crisis Group (2003) Thessaloniki and After I: The EU's Balkan Agenda Brussels: ICG, 20 June, pp. 5-7.

17 International Commission on the Balkans (2005) The Balkans in Europe's Future Sofia: Centre for Liberal Strategies. 
around 2020. ${ }^{18}$ Indeed, the SAP should definitively not be perceived as a fast track integration but as a gradual process following a slower pace than the earlier waves of accession.

There were some key factors which provoked 'enlargement fatigue' and which called for a 'pause for reflection'. Firstly, the previous enlargements of 2004 and 2007 had some shortcomings: the problematic case of Cyprus (which joined the EU as a stilldivided country on the mistaken assumption that accession would hinge on overcoming the partition of the island in accordance with the UN plan); the Slovak-Hungarian bilateral problems; and, above all, the Bulgarian and Romanian EU accessions, which were considered by many as premature, with the two countries showing some serious deficits in their political and moral economies. The consequence is that bilateral tensions in the Balkans and contentious issues will be closely monitored, while the corruption and rule of law indices will be scrupulously vetted. Certainly, there will be no further enlargement where there are unresolved partitions or problematic statehood: EU integration requires strong and functioning states. This clearly sets the agenda for the (potential) candidate countries.

Secondly, there is the issue of the EU's limited 'absorption capacities': ${ }^{19}$ above all, the recent lack of an institutional framework for resuming the enlargement process following the rejection of the draft EU constitution by France and the Netherlands in May 2005. In fact, there is nothing new about this: during the accession process of central and eastern European countries in the late 1990s, the focus on the applicants' conformity with the EU was already being used as a smokescreen to cover the unwillingness of the EU to reform itself so as to fit new members in. This also gave the signal to candidate countries that they were not particularly welcome. The EU is losing most of its appeal in south-east Europe, but a clear signal should be given that the EU sticks by its Thessaloniki commitment.

Thirdly, the slow progress in south-east Europe and the, to some extent, unanticipated setbacks - often described as 'reform fatigue' and local disenchantment. On the one hand, the Balkans are still in a long process of an as-yet unfinished transition with some countries combining the problems of transition with the challenges of development. ${ }^{20}$ On the other hand, the 'pull factor' and the stimulus for reforms, although

18 See Commission of the European Communities (2004) Proposal for a Council Regulation Establishing an Instrument of Pre-Accession Assistance Brussels: COM (2004) 627 final, 29 September.

19 The EU's capacity to absorb is the fourth 'Copenhagen condition' set at the Copenhagen European Council in 1993. Various authors have suggested correctly that the 'absorption capacity' is better deconstructed into more precise and objective components, such as the capacity of the EU's internal market, labour market, budget, eurozone and institutional system to absorb new Member States; society's capacity to absorb immigration; and the EU's capacity for assuring its strategic security. See Michael Emerson, Michael Senem Aydin, Julia De Clerck-Sachsse and Gergana Noutcheva (2006) Just What Is this 'Absorption Capacity' of the European Union? Brussels: CEPS, September.

20 See Alina Mungiu-Pippidi, Wim van Meurs and Vladimir Gligorov (Eds.) (2007) Plan B$B$ for Balkans: State Building and Democratic Institutions in Southeastern Europe Vienna Berlin, Nijmegen, October, p. 55. 
they have not completely vanished, are less convincing today. Thus, after visa liberalisation - at the time of writing, only Kosovo is not on the Schengen list, granting visafree travel to citizens across much of the EU - the EU needs to make the prospect of membership more concrete and visible to people in order that they may buy in to domestic politics.

Fourthly, there is Turkey's multifaceted role. Its own accession process remains blocked and EU public opinion shows strong reluctance to Turkey's membership, but the new Turkish assertiveness as an international player - remarkably active to great effect in south-east Europe - must be taken into consideration. The tricky question is: should the EU, for the sake of political feasibility, decouple the accession process for south-east Europe from that of Turkey? As a matter of fact, south-east European accession is only about the completion and consolidation of the EU's integration - thus finishing the job initiated in early 2000 with the fifth enlargement. In this respect, Turkey represents the greatest challenge to the forthcoming enlargement. The point is that both issues suffer a lack of consensus among EU member states, but in south-east Europe and in Turkey, the EU's own credibility has significantly decreased while the political cost to those advocating accession has notably increased. It is thus urgent that the EU finishes its job in the western Balkans and prioritises Turkey's membership in order also to anchor the latter to Europe. ${ }^{21}$

Meanwhile, more and more serious doubts are being openly formulated on the future of European enlargement. Timothy Garton Ash, director of the European Studies Centre at St. Antony's College, Oxford, has expressed a rationale behind this gloomy mood:

Thus far, enlargement has strengthened, not weakened, the EU. But at some point, continuous extension must end up weakening the Union (...) If the Union were to include all the remains of the Ottoman Empire, it might end up sharing the fate of the Ottoman Empire. ${ }^{22}$

This viewpoint and similar stances - mostly under the pressure of domestic politics - indicate that the prospect of integrating south-east Europe is increasingly viewed with alarm and also convey the impression that the EU is about to pull away from its commitment made at Thessaloniki in 2003. This pessimistic view, often related to a decontextualised misperception of the region, legitimates a prolonged accession process characterised by strict conditionalities and extensive guidance. ${ }^{23}$

\section{Imbalance between the technical and political levels}

Between 2005 and 2009, south-east European countries were thus confronted with a double bind. On the one hand, enlargement faced three scenarios: to slow down; be frozen; or even - as the worst case scenario - cease altogether unless the then 25member EU proved able to cope with more members. On the other hand, the EU re-

21 See Carl Bildt, Franco Frattii, William Hague and Alexander Stubb (2010) 'Europe, look outward again' International Herald Tribune 11 December, p. 7.

22 Timothy Garton Ash (2005) 'For a Pax Europeana' The Guardian 14 April.

23 See Mungiu-Pippidi, van Meurs and Gligorov (Eds.) (2007) op. cit. p. 14. 
peatedly reiterated its readiness to carry its 'responsibility' to support stability and progress in the region and to 'help' the countries there pass through the portal towards candidacy for membership. However, it insisted equally on the importance of:

Carefully managing their accession and how much the integration process required hard work and difficult decisions.

Consequently, the reform process slowed down in south-east Europe and domestic politics gained in importance - the latter of which applies also to the EU.

South-eastern Europe is also facing an accession process which, from one enlargement wave to the next, has become more demanding: negotiations have been subjected to much more stringent tests and have become much more technical. ${ }^{24}$ The SAP principles include the 1993 Copenhagen Criteria for accession and two extra conditions: regional co-operation, and co-operation with the ICTY; and additional country-specific conditions which had to be met before an SAA could be signed. This makes the process both more complicated and longer. This performance- and conditionality-based scheme was confirmed by the 'enlargement consensus' adopted in 2006. This enhanced the rules governing accession, introducing strict conditionality at all stages of negotiations, and refused to set any target dates for accession until negotiations were close to completion. ${ }^{25}$ Consequently, the technical examination of the acquis communautaire undertaken by the European Commission (generally known as 'screening'), introduced at an early stage, before the Opinion and award of candidacy status, makes the entire process stricter - the intention being that 'the increased technicality intends to facilitate the process'.

Additionally, in contrast to what happened in previous enlargement rounds, the EU is now more directly involved in the institutional development and decision-making processes of the next group of potential EU member countries. Indeed, the accession process of south-east European countries is more complex, also as a result of the specifics and the pitfalls of the triple transition to a free market, to a liberal democracy and from war to peace. However, the EU cannot simply duplicate the pattern successfully implemented in central Europe. Therefore, it needs to rethink the mostly standardised strategies and instruments of enlargement and adapt some of the instruments already deployed in south-eastern Europe. ${ }^{26}$

24 See Heather Grabbe (2006) The EU's Transformative Power: Europeanization through Conditionality in Central and Eastern Europe Basingstoke: Palgrave, pp. 14-18.

25 See European Council (2007) Presidency Conclusions of the Brussels European Council 14-15 December 2006 Brussels: Council of the EU, 12 February 2007, 16879/1/06, REV 1, p. 3.

26 A fine-tuned analysis of the patterns of transition reveals that, while some former Yugoslavia republics, such as Croatia and Slovenia, are closer to the central European model, others are closer to the eastern Balkans one. Nevertheless, in more general terms, south-eastern Europe is presently coping with largely the same problems as Bulgaria and Romania. Thus, what worked in Romania and Bulgaria stands a good chance of working in south-east Europe as well, concludes the report published by Mungiu-Pippidi, van Meurs and Gligorov (Eds.) (2007) op. cit. pp. 46-50; and pp. 58-59. 
The academics leading the Captive States, Divided Societies research project highlighted that the accession of south-east European countries must be considered as a new - much more protracted and arduous - process,

Despite enhanced transformative power, reform assistance and political guidance provided by Brussels. $^{27}$

The consequence is that:

The integration of the Western Balkans into the European Union in the next decade will be much more of an uphill battle than East-Central Europe's 'return to Europe' ever was. ${ }^{28}$

Similarly, Marie-Janine Calic's assessment from 2005 remains, alas, up-to-date:

The Western Balkans still have a long way to go before they can realistically expect to be accepted as full members of the EU.

Meanwhile, her recommendations are equally valid:

There is no reason to believe that an intelligent combination of political incentives (integration framework) and an adequate and refocused assistance package could not contribute to overcoming the last division within Europe. ${ }^{29}$

The overall trend toward an increasingly technical accession policy obviously increases the imbalance between the technical and the political levels. This is partly due to the European Commission taking responsibility for managing the enlargement process from the early 1990s onwards. More fundamentally, as pointed out by Grabbe:

There was a lack of strategy and coherence in the EU's approach, largely because of the dearth of political leadership in the EU on how to deal with the aftermath of $1989 .{ }^{30}$

Indeed, we may ask several questions. What happened to the European spirit of the 1970s and 80s, when countries such as Greece, Portugal and Spain, which had just emerged from dictatorship and civil unrest, were welcomed into the European community? And where is the political will and enthusiasm for unifying Europe after several

27 Mungiu-Pippidi, van Meurs and Gligorov (Eds.) (2007) op. cit. p. 5.

28 ibid. p. 6.

29 Marie-Janine Calic (2005) The Western Balkans on the Road Towards European Integration Bonn: Friedrich Ebert Stiftung, December, p. 14.

30 Grabbe (2006) op. cit. p. 28. 
decades of division subsequent to the accession of central and eastern European countries? $?^{31}$

For the time being, there is no breakthrough. We may remind ourselves also that previous enlargement waves had to cope with resistances and with the discourse of an enlarged Union that was already by then more complex and difficult to govern than before. What is missing is a high degree of consensus - on the accession of south-east European countries - among EU member states, as was the case for the fifth enlargement. Political will and leadership make the difference. EU enlargement in south-east Europe is very much a political project. Given the politicised nature of the accession debate, considering also the political and security issues at stake, the EU needs to rethink its strategy in south-east Europe and, above all, embrace politics in order to make the region work. ${ }^{32}$ A renewed 'EU narrative' and updated strategies could 'reload' the accession process and overcome the current negative consequences of enlargement and accession fatigue.

\section{From Lisbon onwards}

We may now ask to what extent the entry into force of the Lisbon Treaty on 1 December 2009 has addressed these problems. The new treaty indeed removes the technical obstacles to further enlargement and has created the opportunity for the joint implementation of all affairs tools (CFSP and community tools). In spite of this, new obstacles are emerging even though the institutional and financial capacities to proceed with the integration process are now finally available.

For a while, Brussels was busy with the establishment of the second Barroso Commission and the EU's European External Action Service (EEAS) - which, at the time of writing, was still in the process of being established. Last but not least, the new dynamics between the Council, the Commission and the Parliament have still to play out. After all, along with the global financial crisis hitting some of its member states, the Union has to deal with its first disintegrating state (Belgium), while new priorities have influenced the EU's foreign policy during 2010. As for now, the new treaty does not create the impression at all that it would promote the deepening and widening of European integration and enhance the EU's capabilities. The good news is that the European Parliament is much more powerful under the Lisbon Treaty. Parliamentarians have expressed their concern about the current pace of south-east European accession. Notably, the Parliament's Foreign Affairs Committee has become proactive on various Balkan-related issues, as illustrated by the approval of a draft resolution (1 December 2010) urging the Union quickly to complete the process of ratification of the SAA with Serbia.

31 Wolfgang Petritsch (2008) 'The EU must speed-up its Western Balkans enlargement' Europe's World Spring, pp. 80-5.

32 T. K. Vogel (2006) 'Why the EU needs to embrace politics if it wants to make the Balkans work' in: Denisa Kostovicova and Vesna Bojičić-Dželilović (Eds.) Austrian Presidency of EU: Regional Approaches to the Balkans Vienna: Centre for the Study of Global Governance and CEIS, pp. 62-70. 
The current financial crisis - targeting Greece, Ireland, Portugal and other member states - obviously has a negative impact on the perception of south-east Europe, but the overall economic situation in the region deserves specific attention. ${ }^{33}$ Despite remarkable rates of growth in GDP up to 2009, GDP growth in 2009 was still lagging behind the 1989 level in Serbia, Bosnia and Herzegovina and, possibly, in Montenegro; labour markets have not shown significant improvement; greenfield investments are scarce and foreign direct investments are still limited; and, finally, the globally poor business environment is having a negative impact on job creation. Substantial economic growth is necessary to underpin the reform process required for EU accession. The prospect of EU membership could act as a short-term incentive, but the lack of such a perspective is affecting the pace of reform as well as the reforms themselves.

South-east European countries should become more pro-active, introduce and implement substantial reforms and make faster progress, notably in the fields of economic liberalisation and the reform of public administration. The re-branding of the Central European Free Trade Agreement (CEFTA) ${ }^{34}$ as a truly South-East European Free Trade Association (SEFTA) - thus acting as a regional free trade and visa-free movement area on the model of EFTA, created in 1960 - could boost regional co-operation and pave the way for the future accession of south-east European countries while consolidating and developing their economic potential - bringing it progressively up to European standards. The goal would be not to postpone but, on the contrary, to keep the candidate countries on track in their progress towards Europe and eventually to facilitate their membership following the examples of Austria and the Nordic states. This would give south-east European states the opportunity to illustrate that they opted for change rather than for the status quo and to raise the level of mutual trust within the region and between south-east European countries and the EU.

33 For a detailed analysis, see Qerim Qerimi and Bruno Sergi (2009) 'The Global Financial Crisis and the Post-Lisbon Prospects of Enlargement' South-East Europe Review 12(4): 439-60.

34 In 2004 and 2007, central and east European countries and Slovenia left CEFTA when they joined the EU. At the time of writing, the parties to CEFTA are: Albania; Bosnia and Herzegovina; Croatia; Macedonia; Moldova; Montenegro; Serbia; and Kosovo. 
Figure 1 - SEE on the road to Brussels

\begin{tabular}{|c|c|c|c|c|c|c|c|}
\hline & Croatia & $\begin{array}{l}\text { Mace- } \\
\text { donia }\end{array}$ & $\begin{array}{l}\text { Monte- } \\
\text { negro }\end{array}$ & Albania & Serbia & $\begin{array}{l}\text { Bosnia } \\
\text { and } \\
\text { Herzego- } \\
\text { vina }\end{array}$ & Kosovo \\
\hline Feasibility Study & 2000 & 1999 & 2005 & 2002 & 2005 & 2003 & \\
\hline SAA signature & Oct 2001 & $\begin{array}{l}\text { Apr } \\
2001\end{array}$ & Oct 2007 & $\begin{array}{l}\text { Jun } \\
2006\end{array}$ & $\begin{array}{l}\text { Apr } \\
2008\end{array}$ & Jun 2008 & \\
\hline SAA entry in force & $\begin{array}{l}\text { Feb } \\
2005\end{array}$ & $\begin{array}{l}\text { Apr } \\
2004\end{array}$ & May 2010 & $\begin{array}{l}\text { Apr } \\
2009\end{array}$ & & & \\
\hline $\begin{array}{l}\text { Accession } \\
\text { application } \\
\text { submitted }\end{array}$ & $\begin{array}{l}\text { Feb } \\
2003\end{array}$ & $\begin{array}{l}\text { Mar } \\
2004\end{array}$ & Dec 2008 & $\begin{array}{l}\text { Apr } \\
2009\end{array}$ & $\begin{array}{l}\text { Dec } \\
2009\end{array}$ & & \\
\hline $\begin{array}{l}\text { Council requests } \\
\text { an opinion }\end{array}$ & $\begin{array}{l}\text { Apr } \\
2003\end{array}$ & $\begin{array}{l}\text { May } \\
2004\end{array}$ & Apr 2009 & $\begin{array}{l}\text { Nov } \\
2009\end{array}$ & $\begin{array}{l}\text { Oct } \\
2010\end{array}$ & & \\
\hline $\begin{array}{l}\text { Country receives } \\
\text { questionnaire }\end{array}$ & Jul 2003 & Oct 2004 & Jul 2009 & $\begin{array}{l}\text { Dec } \\
2009\end{array}$ & $\begin{array}{l}\text { Nov } \\
2010\end{array}$ & & \\
\hline $\begin{array}{l}\text { Country returns } \\
\text { questionnaire }\end{array}$ & Oct 2003 & $\begin{array}{l}\mathrm{Feb} \\
2005\end{array}$ & Dec 2009 & $\begin{array}{l}\text { Apr } \\
2010\end{array}$ & & & \\
\hline $\begin{array}{l}\text { Commission } \\
\text { publishes avis }\end{array}$ & $\begin{array}{l}\text { Apr } \\
2004\end{array}$ & $\begin{array}{l}\text { Nov } \\
2005\end{array}$ & $\begin{array}{l}\text { Nov } \\
2010\end{array}$ & $\begin{array}{l}\text { Nov } \\
2010\end{array}$ & & & \\
\hline $\begin{array}{l}\text { Council gives } \\
\text { candidate status }\end{array}$ & Jun 2004 & $\begin{array}{l}\text { Dec } \\
2005\end{array}$ & Oct 2010 & & & & \\
\hline $\begin{array}{l}\text { Commission } \\
\text { recommends start } \\
\text { of talks }\end{array}$ & $\begin{array}{l}\text { Dec } \\
2004\end{array}$ & Oct 2009 & & & & & \\
\hline $\begin{array}{l}\text { Accession talks } \\
\text { start }\end{array}$ & Oct 2005 & & & & & & \\
\hline \multicolumn{8}{|l|}{$\begin{array}{l}\text { Accession talks } \\
\text { conclude }\end{array}$} \\
\hline Accession & & & & & & & \\
\hline
\end{tabular}

Sources: ec.europa/enlargement and ecfr.eu, updated by the author.

What should be done need not wait

Against this background, it is highly problematic to think of alternatives out of the box. A proactive approach is greatly needed, whereas an overly optimistic view of the integration process must be avoided. Today, most of the earlier proposals seem outdated. It is illusory to suggest a softening of the conditionality (through junior membership) or a speeding-up of the process (be it through shortcuts or a kick-start package). 
Despite candidate countries having rarely entered the EU individually but rather as part of a 'convoy', there is an overall consensus - in the EU as well as in the region ${ }^{35}$ - in favour of a 'regatta approach' under which all (potential) candidate countries start the process together but reach the finishing line at their own speed - as opposed to a simultaneous accession scheme (the 'convoy'). ${ }^{36}$ Last but not least, the option of an international conference on the model of the Thessaloniki Summit (Thessaloniki II) has never generated support.

The May 2010 European Council Foreign Relations (ECFR) policy brief suggests that some lessons might be learned from the recent visa liberalisation process: clear policy aims, achievable short-term goals and a transparent process may indeed:

Transform a technocratic process into a political imperative, leaving little space for local leaders to make excuses or blame EU bias for their lack of progress. ${ }^{37}$

However, it seems highly improbable that - as the ECFR brief suggests - the questionnaire will be handed out simultaneously to Serbia, Bosnia and Herzegovina, and Kosovo. Almost certainly, all of the six countries concerned will not begin the screening exercises together - instead, each country will be requested, as a prerequisite, to complete accession negotiations. What might happen is that some countries will become part of the same convoy - and Figure 1 suggests which countries might belong to a first, second and third convoy respectively.

Focusing less on the speed of accession and more on the quality of reform achievements could certainly be more effective as well as capable of convincing those affected by 'enlargement fatigue'. As already suggested by the Captive States project team: time spent on the accession process should be well spent. It is important to capitalise - as mentioned above - on the positive trends and to diversify the strategic repertoire, giving more weight to the endogenous potential: genuine and factual changes in the field will make the difference.

Against the background of the war period, each south-east European country has made huge progress, but - to various degrees - each of these is still far from becoming a fully-fledged EU member state. Time is running out on the approach initiated in Thessaloniki back in 2003. Bridging the widening time gap between candidacy status and membership - this implies some eight years from the start of accession talks constitutes the first challenge. A first convoy may be a realistic option for some southeast European countries while 'catch-up' facilities, including early screening, should be offered to those lagging behind - typically Bosnia and Herzegovina and Kosovo.

35 See Gordana Đurović and Milivoje Radović (2010) 'Lobbying for a faster integration track for the Western Balkans Regions' South-East Europe Review 13(1): 223.

36 It is worth noting that, initially, enlargement proceeded in 'waves'; negotiations on different chapters were thus opened simultaneously with countries in a given group. In 1999, the EU abandoned 'waves' for the 'regatta principle' as a more flexible, multi-speed accession process. However, this has largely failed because, by then, strong pressure was being exerted on the Commission to admit certain countries as a group.

37 Heather Grabbe, Gerald Knaus and Daniel Korski (2010) Beyond Wait-And-See: The Way Forward for EU Balkans Policy London: ERFR, p. 3. 
This said, some tangible measures should be introduced during 2011. For example: EU student mobility should be extended to all south-east European countries, irrespective of their respective status in their negotiations with the EU. This proposal, and other similar initiatives, would keep the momentum introduced by visa liberalisation and convince the citizens of south-east Europe that the road toward Brussels does pay off.

A wake-up call both to the EU and to the region that a stark choice must be made is much needed. In this respect, there is a gap between symbolic politics and realpolitik: thus a renewed explicit formal political promise - sustaining momentum and the pace of reform with specific instruments and, as mentioned above, visible measures should formulate a tangible commitment to a strengthened relationship between the EU and south-east Europe and, at the same time, acknowledge the legal and administrative necessities in a flexible way, thus combining policies of transition and development.

The new foreign policy priorities, the diminishing international involvement in south-east European countries and the current financial crisis all contribute to a deepening of the development gap which separates south-east European countries from EU member states. A more promising prospect of EU membership, accompanied by specific strategies to address issues of development and growth, within the framework of a regional cohesion programme favouring social inclusion, could contribute to bringing south-east European countries closer to European standards.

The further the EU expands, the more diversity it will have to embrace and the more flexibility will be required of it. The gap in terms of democracy and culture needs to be considered: it cannot be bridged through political transfers and ticking boxes during a mostly technical accession procedure. Misleading representations of backwardness and legacies which are apparently impossible to overcome must be deconstructed using multi-case analytical comparisons in a broader, European framework. The very idea of partnership has to be reviewed as well: south-east European countries must play a full part in the ongoing debates about the meaning of the common European Union project.

Acknowledging these four gaps with their specificities could help formulate a fresh strategy taking into account the new geo-political context and the region's specificities, avoiding the mistakes made in the previous enlargement round. Compared to the initially over-optimistic expectations, the introduced delay should be used constructively in closing the gaps. In the EU, firstly to view enlargement to the western Balkans as a consolidation of the previous enlargement process; and secondly to review and update some instruments and to market its presence on the ground more strongly. In southeast Europe to proceed more seriously with the accession process and to set up a truly South-East European Free Trade Association which would permit almost immediate access to some EU programmes and resources. Such an approach would combine postindependence state-building and capacity development within the framework of a truly 'member-state-building' strategy. 